\title{
The Teaching Habits of Mind, Their Relationship To Positive Behavior of Social Studies Teachers in Lower Basic Stage In University District - The Capital (Amman)
}

\author{
Jamal Abd Al-Fattah Al-Assaf ${ }^{1, *}$ \\ ${ }^{1}$ Al- Balqa' Applied University (BAU), Tlaa Al Ali, Amman, Jordan \\ *Correspondence: Al- Balqa' Applied University (BAU), Box (11) Postal Code (11953), Tlaa Al Ali, Amman, \\ Jordan. Tel: 962-772-132-626. E-mail: Jamalassaf20032002@yahoo.com
}

Received: June 14, 2017

Accepted: July 4, 2017 Online Published: August 20, 2017

doi:10.5430/jct.v6n2p30

URL: https://doi.org/10.5430/jct.v6n2p30

\begin{abstract}
The study aimed at finding out the relationship between teaching habits of mind and positive behavior among the teachers of social studies in the lower basic stage in the university district in the capital governorate (Amman). The sample of this study was composed of (60) teachers, both males and females, who were chosen by the Stratified Random Sample method. Descriptive correlation approach was conducted by the researcher in this study to answer the study questions. The researcher used the following statistical methods: Pearson correlation coefficient, arithmetic means, and three-way Anova and Manova (Analysis of variance \& multivariate analysis of variance).

The study found the following results: The social studies teachers of the lower basic stage have a mean for the teaching habits of mind and positive behavior aspects. And there is an existence of statistically significant positive correlation coefficients between the areas of the teaching habits of mind scale and the scale as a whole and the areas of positive behavior scale (positive personal behavior, positive academic behavior) and the scale as a whole. The study also pointed out that there are statistically significant differences attributed to the variable of experience, and for the benefit of experts who have more than 10 years of experience, and there were statistically significant differences in the areas of the teaching habits of mind scale attributed to the gender variable, and for the benefit of males in the impulsivity control level, thinking flexibly, creativity, perception, and innovation. As well as there were statistically significant differences in the teaching habits of mind and the positive behavior scale according to the variable of experience, and for the benefit of those with more than 10 years of experience. Moreover, there were statistically significant differences in the areas of positive behavior scale attributed to the gender variable and for the benefit of males from the study sample.
\end{abstract}

This study provided a number of recommendations in light of the results.

Keywords: habits of mind; positive behaviour; social studies teacher

\section{Introduction}

It has become difficult to assess the necessary knowledge of learners needs towards their learning, and their awareness of their future lives, and their surrounding environment, so it was necessary to promote them in accordance with the integrated education mechanisms to help them to grow in a balanced way, and liberate mental energies to adapt to the environment and meet the challenges and variables around them.

As an educational institution is a prominent monument in building and developing the learner's personality through the availability of its educational systems working to establish an integrated learning model in which a student represents the educational process axis, in the shadow of the world which witnesses an information technology scientific revolution, which also is characterized by the high-speed increase of information, circulation and interrelatedness. This predicts that the tomorrow's communities will live in a very complex world, so it was necessary to try to keep pace with the culture and information, because the success in this century will not be written only for those who can achieve a balance between being contemporary with the globalization, and the ability of thinking and creativity, and the use of all energies of the human mind and its cleverness (Al-Luqmany, 2012). 
Something which burdens teachers more burdens due to the fact that their role is in the core of the previous modernity currents. Mental development is a part of what we learn, on which we grow, and the education in this case is responsible to make the learner think effectively. The goal of education is no longer to impart and acquire the content and cognitive skills; rather, to employ this education and to promote learners by developing their mental habits. So, the learner must learn from himself whatever he wants to know and learn, and in the different stages of life, so that lifelong learning becomes the highest goal of education. (Nofal, 2008).

\subsection{Habits of Mind}

Studies and research of cognitive psychology, and human brain studies and thinking have revealed many of the theoretical trends that have been examined in the habits of mind. The most prominent of these theories is the Marzano theory. Marzano (1992) defined the habits of mind according to three basic components:

- Self-organization: It includes self-reflection, planning, perception, and sensitivity towards the feedback.

- Creative thinking: It includes skills to expand knowledge, generate and trust on specific assessment criteria, and maintain them, and generate new and unfamiliar ways.

- Critical thinking: It includes the skills of research, clarity, openness to others, resist impulsivity, take and maintain positions, and sensitivity towards the others.

The Costa and Kellick (2000) classification of the habits of mind is one of the most comprehensive and clear classifications. It is one of the most convincing classifications for explaining and interpreting the habits of mind; it is based on the results of recent research studies on the human brain, and on the Marzano's learning dimension model. The Costa and Kellick classification of the habits of mind is a new mental perspective, because it realizes, integrates and understands the nature of the brain components, technology and society, and it emerges as an educational framework that supports the development of continuous intelligence, creativity and learning.

According to Costa and Kellick, the habits of mind are a combination of intelligent behaviors, cognitive processes and thinking skills. Costa and Kallick have concluded a list of sixteen commonly used habits of minds that can be found in an individual. Based on the theoretical literature and previous studies and the conclusions of Costa and Kallick regarding the habits of mind, they have concluded the description of these habits (Costa \& Kallick, 2003; 2009). This study, however, was limited to eight habits associated with the teaching behaviors of teachers - both males and females - of social studies according to the objective of this study - as follows:

1- "Persisting" means the ability of the individual to carry out the task entrusted to him and to continue to work and not to surrender easily to the difficulties in the course of his work; the persistent person has the ability to analyze the problems that he faces in a systematic way; and he has the ability to use successful alternative strategies in a timely manner.

2- "Managing Impulsivity" means the ability to deliberate and listen to alternative viewpoints and instructions, to deliberate and think before making a vision or developing a work-plan for a task, including the ability to deliberate and reflect on alternatives and outcomes from alternative perspectives, and then develop strategies to deal with the task, and delay in making judgments. This habit also means the deliberation and consideration in problem solving before making judgments about a specific idea, and considering different alternatives and outcomes until the full understanding of dimensions of those problems is realized.

3- "Thinking Flexibility" means the ability of the individual to think about new alternatives, options, solutions, and different perspectives with fluency in speech; the individual who is thinking flexibly has the ability to change his or her mental state when facing a situation or solving a particular problem. This habit also means the looking at old ideas with new vision and creative imagination, suggesting multiple alternatives when solving a problem.

4- "Listening with Understanding and Empathy" means the ability to listen, empathize with and understand the other person's point of view, respect his thoughts and opinions, and respond appropriately to him or her so that he/she can re-conceptualize the concepts, emotions, problems and opinions of others with transparency or add meanings to clarify and interpret them.

5- "Thinking about Thinking" / "Metacognitive thinking" means the ability of the individual to understand the steps needed for his plan of action, describing his abilities and cognitive needs, the ability to evaluate the efficiency of his plan, planning his thinking skills, and the impact of his acts on himself and on others. The thinking about thinking helps an individual to do his job, explain his strategies in decision making, develop 
mental maps and mental experimentation to make sure that work is done before implementation is started, and for monitoring and evaluating plans.

6- "Finding Humor" means the ability to perceive the relationships and situations from an appropriate, original and interesting location, and to accept the other people's humors, to encourage pleasure and fun and to create an atmosphere of fun in dealing with others.

7- "Creating, Imagery and Innovating" means the ability of the individual to improve his style in order to achieve more fluency, detail, innovation and craftsmanship by visualizing himself in different roles, enabling him to examine alternative possibilities from several angles. They are mental paths that arise to achieve creativity, practice original thinking, generate new products, and to use ingenious methods and intelligent solutions of problems.

8- "Learning Continuously": means the ability of the individual to learn continuously and to have confidence coupled with curiosity for knowledge and research; to improve growth, learning, adjustment and self-improvement, and to identify problems, situations, tensions and circumstances as valuable learning opportunities; The individuals who are characterized by this mental habit are fully aware that the experience is not knowing everything but knowing the new and more complex level of work.

Costa \& Kallick, referred to in Nofal (2010), have developed a set of characteristics and outcomes that are achieved by the habits of mind of individuals, which is represented by the teaching behavioral trends of teachers, as follows:

1. "Value" refers to the choice of appropriate intelligent mental behavior pattern rather than other less productive patterns.

2. "Tendency" means a sense of desire or tendency to use a pattern of intelligent mental behaviors.

3. "Sensitivity" means the tendency towards the recognition of appropriate opportunities to use better behavioral patterns in teaching situations.

4. "Ability" means the possession of basic skills and abilities through which intelligent behavior can be applied in teaching positions.

5. "Commitment" is through the continuous seeking to reflect on the performance mental behavior patterns and improve the level of this performance constantly.

6. "Policy" means the integration of mental/rational patterns in all actions, decisions and practices and upgrading them, making it as a public policy that should not be skipped.

\subsection{Positive Behavior}

Since ancient times, human nature has been the focus of scientists, philosophers, and religious scholars. Greek had been concerned to study morality and virtue, and the factors that impact on moral growth, and the existence of an ideal society.

The attention to behavior has begun since ancient times. All divine religions have been concerned with behavior of all kinds, and have urged the promotion of good behavior, away from negative and bad negative behaviors, and they have enacted laws and regulations that prohibit bad behavior and punish of perpetrators. The concern in studying negative behavior rather positive one has remained until the 1960s and early 1970s. Since that time there was a rapid development of interest in the study of positive behavior. (Abdelmaksoud, 2012).

This interest grew in Western psychology after the Second World War. The movement of evolution began to take on the positive attitude of Martin Seligman, the Chairman of American Psychological Association, and the founder of positive psychology, to establish the goals, areas and interests of this science. In addition, he developed the studies of human happiness in the mainstream of psychology field. Psychology, therefore, became not only concerned with the study of disease, weakness and damage, but also became interested in studying the places of strength and human virtues such as happiness and tranquility; hope and psychological stability; social appreciation; conviction, and overcome the pressures suffered by human beings. Many studies and researches have focused on positive behaviors as one of the positive psychology categories (Abdel-Khaliq, 2004). Such intensive studies of positive behavior resulted in scientific determinants, as follows:

- "Social experiences" refer to the interactions of the individual with the social factors around him like parents, colleagues, teachers, and the media that have a crucial role in shaping the individual's responses and tendencies.

- "Personality traits" includes support and socialism. 
- "The vital factor" is included in the genetic factors that affect the difference in individuals in their preparations, and their attitudes towards others.

- "Cultural factor": the actions of the individual, motives, trends and values are affected by the culture derived by the individual. All aspects of behavior and social functions are acquired, and culture determines what the individual learns as a member of a group not more.

- "Cognitive procedures" includes cognitive perception, assessment of the individual's attitude, and ability to see and assess attitudes through the perspective of others, and decision-making ability.

- "Situational determinants": include external pressures, social events that represent an organized force in societal reactions / responses that support the society (Shaqoura, 2013).

Since human behavior is the result of what the individual has learned and acquired during the various stages of his life. Behavior may be positive or negative, and can be accepted or unacceptable. Our judgments, therefore, differ from this behavior according to different standards and cultures and different human societies. We can judge that the behavior is positive if it possesses any of these dimensions, which will be measured by the scale of the positive behavior which was developed by the researcher, represented in both personal and academic dimensions, namely the dimensions that represent the reality of the teacher's role in the field of teaching from the point of view of the researcher.

1- Personal dimension:

The personality of the individual gradually develops through the various stages of his life, and this development involves two important dimensions in the life of the individual represented by both conscious and unconscious sources, and it represents an essential component in building the individual personality and self-realization, through the idea that the individual builds about himself. If his view about the life is optimistic, he is characterized as flexible, subliminal, self-confident, tranquil, hopeful, and self-sufficient, and he appreciates his personal, professional and social needs, and he feels a sense of competence, satisfaction and love of others, and he is patient to attain a better future with self-esteem and holding his rights. Also, he finds himself able to confront crises with reason and thought (Mahmoud, 2012: 12). The researcher believes that the primary role of the teacher is to refine and develop the personality of the learner, and what the student feels towards himself, and to form his future image with all the positive and pleasure. The personal harmony of the learner is highlighted by the extent of possessing positive behaviors and employing them in different classroom and life situations, of which the teacher contributes to effectively achieve it for his student.

\section{2- Academic Dimension:}

The time that the individual spends in learning is responsible for a large part of an individual's life. The academic success and excellence are desirable and important requirements for each individual, his or her family and the surrounding society. There are many literatures that emphasized the impact of academic success on the course of an individual's life by influencing their academic choices and professional aspirations as well as their psychological, social, and public interest development (Barbakh, 2015). The researcher believes that this study aimed at scaling the teacher's ability to interact academically with the school environment in which he is present, and this is evident through his ability to focus and employ his mental and cognitive abilities to guide the growth of learners to the positive academic growth towards the change for the better, along with serious aims of research and teaching through seeking to apply everything that is new, fruitful and useful by using modern techniques in the field of teaching, by measuring a set of standards that enhance the degrees of using the positive academic behavior of teacher and its compatibility with the school environment.

Hence, the researcher's diligence in building the aim of his study was achieved by his attempt to invest some of the teaching habits of mind and directing their behavior towards behavioral commencement in the field of teaching by the teacher of social studies, and by linking these habits and knowing their relationships with the positive behavior, which is one of the goals of positive psychology, and they are integrated. The result of cognitive, cultural, emotional and psychological aspects of teachers is reflected positively on the behavior of students and the refinement of their personalities, in various aspects of life. The positive personality traits of the teacher affect his academic and personal performance.

Personal theories have shown that the individual's personality consists of relatively fixed characteristics that are demonstrated in the patterns of his usual behavior. These characteristics are only the result of common factors arising from genetic factors that evolve and interact with environmental factors. Campbell (2006: 3) emphasizes that it is important for teachers to have a deep understanding of the habits of mind, and of their own practices, so that they can 
build and direct those habits in the behavior of their students, and verify their representation and achievement, which makes the teacher competent in his teaching practices.

The common denominator among social studies, teachers and habits of mind is the activity of the mind through the analysis, recall, synthesis, interpretation, and through the guidance of learners towards effective thinking, curiosity of knowledge, flexibility, understanding of problems, decision making, logical conduct, mutual thinking, development of sense of intuition, experimentation and the formation of logical relationships among the ideas and interaction between them. The main aims of social studies as defined by (Thomas Terns, 2005, 577) are: To prepare a citizen capable of taking responsibility towards his society, in which he lives and the world community as a whole in its various contemporary issues and the possession of a conscious vision to solve his problems by a global clear-sightedness. This can only be achieved through the acquisition of positive habits of mind teachers by teachers in order to improve the learners in all the above-mentioned.

This study seeks to reveal the nature of the relationship among the teaching habits of mind and their relationship to the positive behavior of the teachers of social studies in the light of some variables.

Many studies have previously examined the variables of this study. Khoon (2005) conducted a study aimed at identifying the effect of the habits of mind on the achievement of secondary school students. The study sample composed of (163) students. The researcher, for purposes of the study, used a number of tools to evaluate the thinking skills of students (The GALT (Group Assessment of Logical. Thinking, Critical Thinking Skills Test). The results of the study showed that the thinking skills of the students of the treatment group who experienced the habits of mind improved significantly compared to the control group, where they showed an improvement in the subjects in which they were tested in the tests of logical and critical thinking, which shows that the habits of mind affected the performance of students.

Rodgers (2008) also conducted a study in USA aimed at showing the impact of employing the habits of mind in the classroom to improve the students' achievement. The study sample composed of (38) students, and the students were divided into two equal groups: The experimental group was studied by six mental habits: perseverance, flexible thinking, seeking accuracy, activity, probing questions, creativity and imagination. While the control group was studied in normal ways, and a post-test was conducted for the two groups. The results showed that the use of mental habits in the teaching of the experimental group increased the academic achievement more than the control group. The results of the study also showed that these habits of mind enabled the students to employ higher thinking skills and creative thinking in the study.

Erian (2010) conducted a study aimed at knowing the "habits of mind and the skills of social intelligence required for the teacher of philosophy and sociology in the 21st century in Egypt". The sample composed of 75 teachers for the academic year 2008/2009. The study resulted in showing that all the habits of mind have a very high importance for teachers of philosophy and sociology.

Al-Luqmani (2012) conducted a study aimed at showing the exercise degree of female kindergarten teachers in Mecca Al-Mokarama of habits of mind and its relationship with some variables. The study sample composed of (121) female kindergarten teachers. The results of the study showed that the exercise degree of habits of mind in the sample of the study was high, and there were no statically significant difference of the exercise degree of female kindergarten teachers in Mecca Al-Mokarama of the dimensions of the habits of mind, attributed to the variables of the study (age, educational qualification, years of educational experience, and the number of training courses).

Shaqura (2013) conducted a study aimed at identifying the relationship between positive behavior and productive behavior of the students of technical colleges in Gaza Strip in Palestine. The sample composed of (388) male and female students. The results of the study showed that there was a positive relationship between positive behavior and productive thinking, and there was an effect of positive behavior and for the benefit of the rates (80) and above. There were statistically significant differences of for the gender variable and for the females of the study sample.

Al-Nuwab and Hussein (2013) conducted a study aimed at finding out the level and order of the habits of mind and their sequence and relationship to high-level thinking and self-efficacy among the students of the faculties of education. The study sample composed of 233 students - both males and females. The results showed that the study sample possessed all the habits of mind, but at relatively low levels. The results also showed that there was a relationship between the habits of mind, high-level thinking and self-efficacy, and the habits of mind contributed to the self-efficacy.

Al-Qudah (2014) conducted a study aimed at finding out the habits of mind and their relationship to the motivation of achievement among the students of the Faculty of Education. The study sample composed of 202 students from 
the Faculty of Education, King Saud University. The results of the study found that the level of possession of the habits of mind among the students of Faculty of Education was high.

Barbakh (2015) conducted a study aimed at finding out the relationship between the habits of mind and the positive behavior aspects among the students of Al-Azhar University in Gaza Strip and finding out whether there are differences in both the habits of mind and positive behavior attributed to the educational level, specialization, and gender. This sample was randomly selected. The results showed that the level of possession of the habits of mind among the students of Al-Azhar University, and the aspects of positive behavior were high. And there was a statistically significant positive relationship among all the dimensions of the habits of mind and the total score of the scale of positive behavior, and positive social behavior.

It is clear from the previous presentation of the previous studies that dealt with the habits of mind and positive behavior varied in terms of the environments in which there were conducted as there were Arab and foreign studies. Most of the studies to which they referred, had used the descriptive method. For this study, the researcher followed the example of those who used the descriptive correlational method because of its compatibility with this study.

The researcher did not find a model in the previous studies which determines the relationship between the teaching habits of mind and positive behavior of the teachers of social studies, but the previous studies dealt with - one way or another - some relative variables or concepts. The researcher tried to benefit from those studies to support this study and through enriching the theoretical framework and development of study tool. The researcher found that the studies on these two variables, especially on teachers and teachers of social studies in the Arab and Jordanian environment, were still very rare. This study differed from previous studies in its purpose, population and variables. Perhaps the most important characteristic of this study is the choice of two variables: 1) the teaching habits of mind, and 2) the positive behaviors, both were relatively recent variables in the psychological and educational sciences. For the limits of the researcher's knowledge, the studies - related to their method, terminology, and style - are still very few and rare according the limits of the researcher's knowledge.

\section{The Research Problem and Question}

The development of teachers' performance is an important indicator of the development and progress of societies. The category of social studies teachers is an integral part of this development and progress.

These teachers may have teaching habits of mind that enable them to use positive and intelligent behaviors in coping with the problems they face in teaching situations. With the exception that this category is educational absolute necessity for the formation of students who are able to meet the challenges and solve the problems that face them and motivate them to achieve in their future. The learner, therefore, can organize the knowledge stock and manage his ideas, and help him find solutions to the problems that he faces.

It is also possible that these positive habits and behaviors provide student with self-confidence and play an important role in the level of thinking and performance and his love for this subject matter. The researcher found that there was a new and extensive area to look for the relationship among the teaching habits of mind and positive behaviors of social studies teachers; given that the research and studies in these two subjects are still very low in the level of local, Arab and foreign studies in this category of teachers. The researcher believes that the study of the teaching habits of mind and positive behaviors may have an important role in the probing and survey of strength and weakness of these two subjects in the social studies teachers category, which helps design future programs and holding appropriate training workshops that will develop the teaching habits of mind and positive behaviors of the teachers of social studies. Through the researcher's knowledge of previous studies in this field, he has not found within the limits of his knowledge any Arab or foreign study that is concerned directly with studying the relationship between the teaching habits of mind and positive behaviors of teachers of social studies, which gives the importance and justification to address and study this problem. Based on this, the problem of this study can be identified in an attempt to answer the following questions:

1. What is the level of teaching habits of mind among teachers of social studies of the lower basic stage?

2. What is the level of positive behavior among teachers of social studies of the lower basic stage?

3. Is there a statistically significant relationship among the teaching habits of mind, and the positive behavior of the teachers of social studies in the lower basic?

4. Are there statistically significant differences in the teaching habits of mind among the teachers of social studies of the lower basic stage according to the variables (gender, experience, and educational qualification)? 
5. Are there statistically significant differences in the positive behavior of the social studies teachers of the lower basic stage according to the variables (gender, experience, and educational qualification)?

\section{Objectives of Study and Importance}

- Explain the relationship among the teaching habits of mind, and the positive behavior of the teachers of social studies of the lower basic stage.

- Identify the differences in each of teaching habits of mind, and the aspects of positive behavior depending on the variables: educational qualification, experience, and gender.

The Importance of this study is reflected in the following:

\subsection{Theoretical Importance}

- Being one of the rare studies within the limits of the researcher's knowledge, this dealt with the problem of study specifically in the field of specialization social studies and their teachers.

- Consistent with the increasing interest at the global level in the habits of mind and the extent of its importance for the teachers.

- This study should be an important and useful factor to draw the attention of experts and specialists in the programs of teacher education for developing the teaching habits of mind and positive behavior among teachers of social studies.

\subsection{Practical Importance}

- Contribute to the construction of programs, and the development of plans and mechanisms to develop the teaching habits of mind of social studies teachers.

- Direct the attention of those involved in the educational-learning process towards the attention for the development of habits of mind in teaching.

- The curricula and subject-matter of social studies should include practices of the teaching habits of mind and its various applications within the classroom.

\section{Terminology of Study}

-"Habits of Mind": Cost \& Kallick (2003) defined the habits of mind as the tendency of the individual to behave intelligently when facing a problem, when the answer or solution is not available in his knowledge structure; the problem may be puzzling in the form of the position, or enigmatic, or ambiguous position, the habits of mind imply to employ intelligent behavior when the individual does not know the answer or the appropriate solution.

The procedural definition of "Habits of Mind" means "The degree by which the members of this study sample obtain the scale of the teaching habits of mind used in this study."

- "Positive behavior" means the sum of socially acceptable behaviors and methods of the individual, which are conducted voluntarily and without any restrictions, and they are accepted by the individual psychologically and intellectually, and they have positive consequences for the individual and the surrounding society.

The procedural definition of "positive behavior" means the degree, by which the teacher obtains the scale of positive behavior that is represented in all the following aspects: academic and personal aspects.

- Teacher of Social Studies: The individual who is appointed by the Ministry of Education in Jordan to teach the subject- matters of (history, geography, and national education) for the academic year 2016-2017.

- "The lower basic stage" means the educational stage, which extends from the first grade until the basic sixth grade, according to the system of the Ministry of Education in Jordan.

\section{Study Limitations}

- The study tool is the scale of the teaching habits of mind level and their relation to the positive behavior of the social studies teachers of the basic stage in the educational University district in the capital Amman. This tool was developed for the purposes of this study. The interpretation of the results, therefore, depends greatly on the degree of the tool validity, and on its degree of reliability. Noting that, the validity and reliability of the study tool has been verified. 
- The study was limited to the teachers of social studies for the basic stage in the educational University district in the capital Amman. This limits the dissemination of the study results to teachers of other subjects, and other educational areas.

- It is also limited to the procedural definitions of the listed terms, and the characteristics of the used statistical treatments/ processors.

- This study is limited to some of teaching habits of mind, and represented in the following habits (Persisting; Managing Impulsivity; Listening with Understanding and Empathy; Thinking Flexibility; Thinking about Thinking / Metacognitive thinking; Creating, Imagery and Innovating; Learning Continuously; Finding Humor), and the habits according to the scale of Positive Behavior which are represented in (positive personal behavior and positive academic behavior). This limits the generalization of the study results to all habits of mind.

\section{Research Methodology}

The descriptive correlational method has been used because of its Compatibility with the study nature. It is the most appropriate way to obtain information to achieve the study objectives, by which we can monitor the reality as it is in its field by quantifying it in digital description.

\subsection{Study Population}

The study population composed of all social studies teachers - both males and females- for the lower basic stage of (history, geography, and national education) in the Directorate of Education in the Capital Governorate (University District), including (228) teachers according to statistics of the Ministry of Education for the academic year (2016/2017).

\subsection{The Study Sample}

The study sample composed of (60) teachers -both males and females- in the directorates of education in the university district in the capital Governorate (Amman). (38\%) of the population size was chosen by the Stratified Random Sample method according to the variables of educational qualification, experience, and gender. Table (1) shows that:

Table 1. The Distribution of Sample According to the Variables of the Study

\begin{tabular}{llll}
\hline Variables & Categories & Repetition/duplicate & percentage \\
\hline \multirow{3}{*}{ Gender } & Male & 28 & 46.7 \\
& Female & 32 & 53.3 \\
& Total & 60 & 100.0 \\
Educational Qualification & BA & 34 & 56.7 \\
& Postgraduate & 26 & 43.3 \\
& Total & 60 & 100.0 \\
Experience & $1-5$ years & 20 & 33.3 \\
& 6- 10 years & 25 & 41.7 \\
& More than 10 years & 15 & 25.0 \\
& Total & 60 & 100.0 \\
\hline
\end{tabular}

\section{Study Tools}

For the purposes of achieving the study objectives, two tools were used to detect the level of teaching habits of mind and positive behavior of the study sample. The descriptions of these two tools are as follows:

First - The Scale of Teaching Habits of Mind:

The researcher benefited - for the development of the final shape of The Scale of the Teaching Habits of Mind in this study - from the standards that were developed on the Arab environment such as Al-Luqmany study (2012) and Barbakh study (2015) and on the Jordanian Environment such as Al-Qudah study (2014). This study was verified at first by the arbitrators and taking their recommendations and edits into consideration in the compatibility with the study sample. The Scale of the Teaching Habits of Mind, whose items of its areas were elaborated in accordance with the behaviors directly related to the field of teaching in this study, was composed of (45) items distributed on (8) 
teaching habits of mind, namely: (Persisting; Managing Impulsivity; Listening with Understanding and Empathy; Thinking Flexibility; Thinking about Thinking / Metacognitive thinking; Creating, Imagery and Innovating; Learning Continuously; Finding Humor). each of these habits was scaled by (5) items. The researcher in this study has verified the validity and reliability of habits of mind scale on the study sample as follows:

The "scale validity": The researcher in this study verified the validity of the teaching habits of mind and positive behaviors scale by the two ways of content validity and the internal consistency validity (Construct Validity), as follows:

The content validity (the arbitrators) for the validity of the teaching habits of mind and positive behaviors scale: the content validity was confirmed by the presentation of the two scales (teaching habits of the mind and positive behaviors) by a group of academic professors specializing in educational psychology and teaching methods in more than one university - both Jordanian and Arab universities. These professors have expressed their opinions and notes about the scale items and the extent of their compatibility and suitability with each field to which they belong to. The $80 \%$ criterion was adopted to keep the items. Based on the opinions and observations of the arbitrators' committee, they did not recommend deleting any item. The suggestions of the arbitrators' committee and their amendments were settled for the change of some language formulations and replacing some of the repeated words in some items to suit the meaning and expression of the field to which they belong, and in accordance with the nature of the study sample.

The indicators of the validity of the teaching habits of mind and positive behaviors scale:

To verify the Construct Validity, the Pearson correlation coefficient among the the teaching habits of mind and positive behaviors scale items and degrees of each dimension, were calculated. The Table (2) shows that:

Table 2. The Values of Correlation Coefficients among the Teaching Habits of Mind and Positive Behaviors Scale Items and Degrees of Each Dimension

\begin{tabular}{|c|c|c|c|c|}
\hline \multirow{2}{*}{ The dimension } & \multirow{2}{*}{$\begin{array}{l}\text { Item } \\
\text { number }\end{array}$} & \multicolumn{3}{|c|}{ The items content of teaching habits of mind according to the Linked with: } \\
\hline & & dimensions & Dimension & Scale \\
\hline \multirow{5}{*}{ Persisting } & 1 & I work hard with activity to get the highest annual estimates & .924 & .881 \\
\hline & 2 & $\begin{array}{l}\text { I make a great deal of effort to perform the hard work in } \\
\text { teaching positions }\end{array}$ & .830 & 7.86 \\
\hline & 3 & $\begin{array}{l}\text { I'm trying to focus and persist on the mission of teaching } \\
\text { even though it is not enjoyable. }\end{array}$ & .950 & .752 \\
\hline & 4 & $\begin{array}{l}\text { I overcome difficulties in order to achieve my educational } \\
\text { purposes. }\end{array}$ & .881 & .591 \\
\hline & 5 & $\begin{array}{l}\text { if I failed in the clarification of a task, I search about another } \\
\text { method }\end{array}$ & .836 & 6.80 \\
\hline \multirow{6}{*}{ Managing Impulsivity } & 1 & I think well before I act & 719 & .472 \\
\hline & 2 & $\begin{array}{l}\text { I think quietly when I face a difficult position in the field of } \\
\text { teaching }\end{array}$ & 874 & .421 \\
\hline & 3 & I answer quickly regardless the content of my answer & 874 & .335 \\
\hline & 4 & $\begin{array}{l}\text { I think well before I make the decision to solve a certain } \\
\text { problem. }\end{array}$ & 930 & .542 \\
\hline & 5 & I prepare typical answers to give the accurate answer & .792 & 414 \\
\hline & 6 & I am slow at answering the questions submitted by students & 693 & .542 \\
\hline \multirow{5}{*}{$\begin{array}{l}\text { Listening with } \\
\text { Understanding and } \\
\text { Empathy }\end{array}$} & 1 & $\begin{array}{l}\text { I listen will all my senses to those who are talking with me- } \\
\text { both my students and my colleagues. }\end{array}$ & .277 & 630 \\
\hline & 2 & $\begin{array}{l}\text { I Listen to me my colleagues and my students, and I assess } \\
\text { their thoughts }\end{array}$ & .810 & .566 \\
\hline & 3 & I listen to and share the feelings and thoughts of others & .935 & .681 \\
\hline & 4 & $\begin{array}{l}\text { I do not imitate the way in which the speaker expresses his } \\
\text { emotions }\end{array}$ & .932 & .736 \\
\hline & 5 & I listen to my colleagues even if they opposed my thoughts & 604 & .580 \\
\hline Thinking Flexibility & 1 & I have open mind to receive the information & .792 & .277 \\
\hline
\end{tabular}




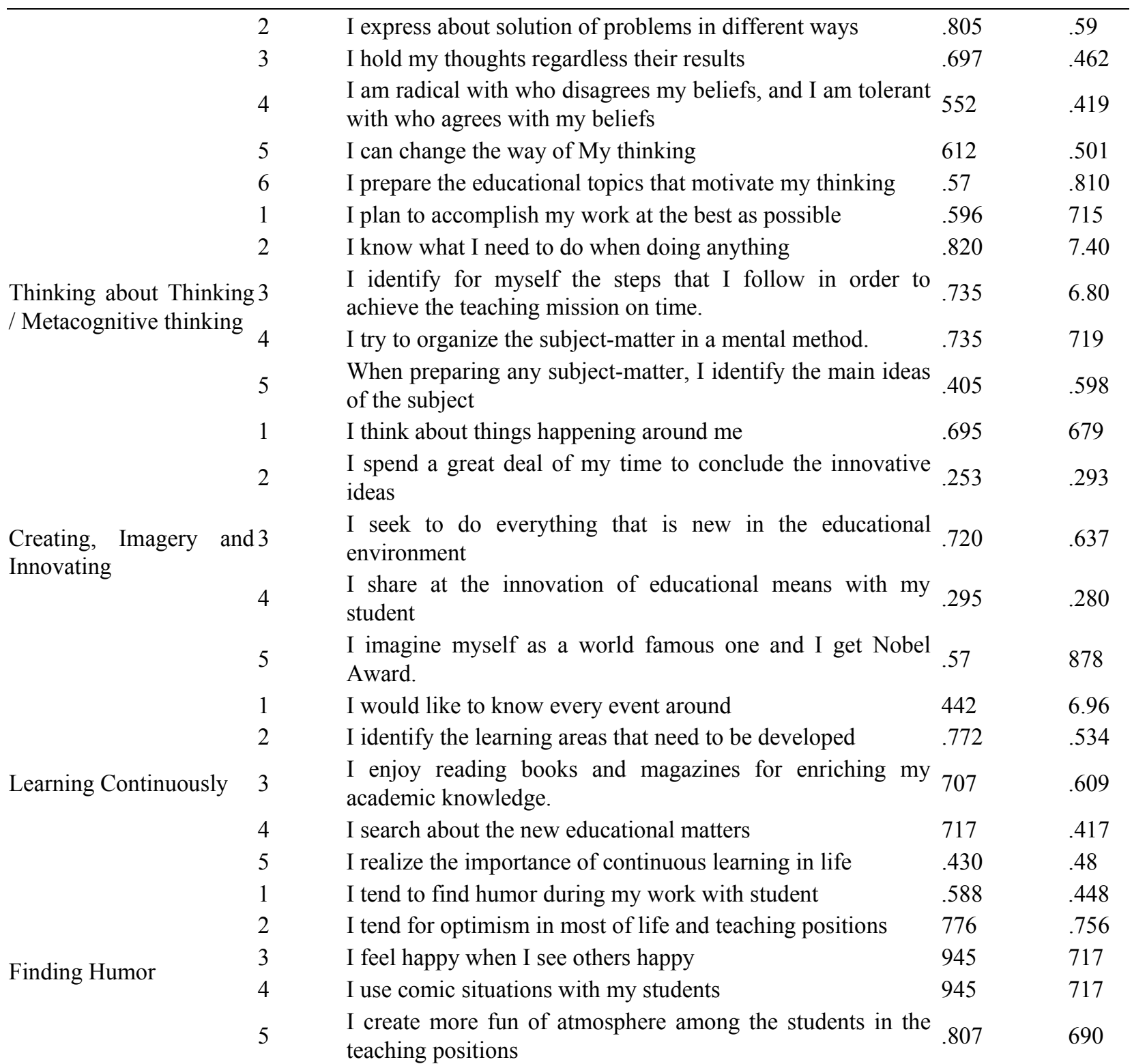

* Significance level of $(0.05)$

** Significance level (0.01)

It is noted in the Table (2) that the values of correlation coefficients of the items with dimension ranged between $(0.253-0.950)$ and with the scale between $(0.881-0.280)$. A criterion for the acceptance of the item was adopted that the correlation coefficient is not less than 0.20 . All scale items with correlation coefficient higher than 0.20 , therefore, were accepted, and none of the scale items was deleted.

\section{The reliability of teaching habits of mind scale:}

The internal consistency coefficients of the proper habits of mind scale dimensions for the survey sample results were calculated. Internal consistency coefficients ranged by using the Cronbach's alpha equation for subfields between $(0.71-0.95)$, the total scale $(0.96)$. Table (3) shows this: 
Table 3. The Internal Consistency Coefficients of the Proper Habits of Mind

\begin{tabular}{lll}
\hline Area/ field & $\begin{array}{l}\text { Cronbach's alpha } \\
\text { Coefficient }\end{array}$ & Number of items \\
\hline Persisting & 0.95 & 5 \\
Managing Impulsivity & 0.93 & 6 \\
Listening with Understanding and Empathy & 0.92 & 5 \\
Thinking Flexibility & 0.85 & 6 \\
Thinking about Thinking / Metacognitive thinking & 0.81 & 5 \\
Creating, Imagery and Innovating & 0.71 & 5 \\
Learning Continuously & 0.81 & 5 \\
Finding Humor & 0.92 & 5 \\
Total scale (macro) & 0.96 & 42 \\
\hline
\end{tabular}

\section{Second: Positive Behavior Scale}

The researcher has benefited from the preparation of the final form of positive behavior scale in this study using the scales developed on the Arab environment such as the study of Shaqura (2013) and the study of Barbakh (2015), after presenting them to the arbitrators and taking their recommendations and amendments in compatibility with the study sample. The final form of the scale composed of (20) items at two-dimensions, namely the academic dimension and the personal dimension, so that each item/statement expresses one behavior of the behaviors associated with teacher performance in the field of teaching.

\section{Construction validity Indicators of positive behavior scale}

To verify the construction validity indicators, Pearson correlation coefficients were calculated among the items of positive behavior and the scores on each dimension. Table 4 shows this as follows:

Table 4. The Values of Correlation Coefficients among the Positive Behaviors Scale Items and Scores of Each Dimension

\begin{tabular}{|c|c|c|c|c|}
\hline \multirow[t]{2}{*}{ The dimension } & \multirow{2}{*}{$\begin{array}{l}\text { Item } \\
\#\end{array}$} & \multirow[t]{2}{*}{ The items content of positive behavior according to the dimensions } & \multicolumn{2}{|c|}{ Linked with: } \\
\hline & & & Dimension & Scale \\
\hline & 1 & I select the suitable responses and answers for different positions & .619 & .870 \\
\hline Personal positive & 2 & I effectively face problems and suggest the possible solutions & 668 & .865 \\
\hline \multirow[t]{9}{*}{ behavior } & 3 & I enjoy the peace of mind / Psychological tranquility & 666 & .872 \\
\hline & 4 & I am self-confident & .402 & .292 \\
\hline & 5 & I can predict the behavior of others & .411 & .352 \\
\hline & 6 & I advocate for what I think is true & 657 & .491 \\
\hline & 7 & I care about my external appearance & .465 & .277 \\
\hline & 8 & I feel self-satisfied & .489 & .620 \\
\hline & 9 & I tend to the moderation when dealing with others. & .269 & .347 \\
\hline & 10 & I hold my rights & .431 & .642 \\
\hline & 1 & I can change myself to the better & .410 & .651 \\
\hline Academic Positive & 2 & I comply with the laws and regulations of school systems & .823 & .801 \\
\hline \multirow[t]{8}{*}{ Behavior } & 3 & I follow up new all the educational methods in my major. & .701 & .728 \\
\hline & 4 & $\begin{array}{l}\text { I balance between the conditions of my work and the other } \\
\text { requirements of life. }\end{array}$ & .701 & .615 \\
\hline & 5 & I identify the goals before starting the teaching. & .900 & .746 \\
\hline & 6 & I develop myself through research and training & .731 & .567 \\
\hline & 7 & I am able to understand the new matters in my major. & .799 & .619 \\
\hline & 8 & I comply with the timing of classes. & .717 & .536 \\
\hline & 9 & I believe in using the new technology to exploit time and effort & .502 & .491 \\
\hline & 10 & I work for managing time according to a specific time schedule & .556 & .504 \\
\hline
\end{tabular}


It is noted in the Table (4) that the values of correlation coefficients of the items with dimension ranged between (0.269- 0.90) and with the scale between $(0.870-0.277)$. A criterion for the item acceptance was adopted that the correlation coefficient is not less than 0.20 . All scale items with correlation coefficient higher than 0.20 , therefore, were accepted, and none of the scale items was deleted.

\section{The reliability of positive behavior scale:}

The internal consistency coefficients of the proper positive behavior scale dimensions for the survey sample results were calculated. Internal consistency coefficients ranged by using the Cronbach's alpha equation for subfields between $(0.75-0.91)$, the total scale (0.86). Table (5) shows this:

Table 5. The Internal Consistency Coefficients of the Teaching Positive Behavior Scale

\begin{tabular}{lll}
\hline Area/ field & $\begin{array}{l}\text { Cronbach's alpha } \\
\text { Coefficient }\end{array}$ & Number of items \\
\hline Personal positive behavior & 0.75 & 10 \\
Academic positive behavior & 0.91 & 10 \\
Total / for the scale & 0.86 & 20 \\
\hline
\end{tabular}

"Scale Correction" is the obtainment of score for each individual in the sample that his response is represented to each item of the scale. The triple grading is adopted and its substitutes are given the following grades: (3) degrees are applied often, (2) degrees are applied sometimes, and (1) degree is applied rarely. In order to extract the values significances of the three-dimensional Likert scale, the highest score (3) was subtracted of the lowest grade (1) and divided by the number of degrees (3), i.e. (3-1) divided by (3) and equals 0.66 . The values are as follows: from (1-1.66) indicating a low value for the arithmetic mean, and (1.67-2.33) indicating the mean value of the arithmetic mean, and (2.34-3) indicates the high value of the arithmetic mean.

\section{Statistical Treatment Methods}

To achieve the aims of this study, Statistical Package for the Social Sciences (SPSS) was used to analyze data and obtain the following results

- Duplicates and percentages to describe the characteristics of the study sample.

- The arithmetic means and the standard deviations to identify the responses of the sample members on each of the questionnaire items.

- Pearson Correlation coefficient to verify the internal consistency validity of the questionnaire.

- Cronbach's Alpha coefficient to verify the reliability of questionnaire.

- 3-WAYS MANOVA without interactions to test the significance of differences between variables.

\section{Study Variables}

A - Study variables: (habits of mind associated with teaching, positive behavior).

B - Intermediate variables: Gender: (male, female), scientific qualification: (BA, postgraduate), experience: (1-5 years), (6-10 years) (more than 10 years).

\section{Study Results and Discussion}

Question 1: What is the level of teaching habits of mind among teachers of social studies of the lower basic stage?

To answer this question, the arithmetic means and standard deviations of the scores of the sample were calculated on the area of the teaching cognitive habits scale. Table (6) includes the results: 
Table 6. The Arithmetic Means and Standard Deviations of the Scores of the Sample on the Fields of the Measure of Teaching Habits of Mind

\begin{tabular}{|c|c|c|c|c|c|}
\hline Rank & number of field & The level and areas of teaching habits of mind & $\begin{array}{l}\text { Arithmetic } \\
\text { Mean }\end{array}$ & $\begin{array}{l}\text { Standard } \\
\text { Deviation }\end{array}$ & Level \\
\hline 1 & 8 & Finding Humor & 2.3 & 0.61 & Mean \\
\hline 2 & 5 & Thinking about Thinking / Metacognitive thinking & 2.22 & .463 & Mean \\
\hline 3 & 6 & Creating, Imagery and Innovating & 2.19 & 0.435 & Mean \\
\hline 4 & 3 & Listening with Understanding and Empathy & 2.15 & 0.663 & Mean \\
\hline 5 & 2 & Managing Impulsivity & 2.14 & 0.611 & Mean \\
\hline 6 & 7 & Learning Continuously & 2.12 & 0.439 & Mean \\
\hline 7 & 4 & Thinking Flexibility & 2.07 & 0.499 & Mean \\
\hline 8 & 1 & Persisting & 2.04 & 0.707 & Mean \\
\hline \multicolumn{3}{|c|}{ Macro scale } & 2.16 & 426 & Mean \\
\hline
\end{tabular}

Table (6) shows that the level of teaching habits of mind occurred within the intermediate level. The field of finding humor has the highest arithmetic mean, followed by the field of metacognitive thinking in the second rank, and the field of persisting in the $8^{\text {th }}$ and the final rank where it obtained the lowest arithmetic mean compared to other fields. The researcher finds that this finding is an important challenge for the teacher education programs in the Ministry of Education. It seems that it still focuses on the traditional aspects of preparation and placement on the educational subject matter and educational content without paying attention to the teachers' habits of mind, which is also lacking in the university programs related to teaching professions. Especially at the bachelor level. This is noted by the researcher through the review of those academic programs in a number of universities. But in terms of occupation of the field (Finding Humor) for the first rank of those habits, despite the middle degree in it, the researcher believes that this corresponds to the nature of the educational stage taught by teachers of social studies, the lower basic stage, which is in the category of (9-12) years. The teachers seem to have an awareness - albeit to a medium degree - of this category of age and education of the student that require the tendency to humor and the sense of happiness and the use of sense of humor and create the atmosphere of fun when dealing with them in teaching positions. This corresponds with the field of metacognitive thinking which was ranked as the second. This metacognitive thinking represents the systematic state of the first field, which is the awareness of social studies teachers in the systematic planning to achieve tasks and ideas in teaching positions. While the field of persisting was in the last level of the habits of mind as the educational stage taught by social studies teachers in which there is a progress for the areas of harmonious psychological compatibility and the educational stage of the study sample, which requires humor and the behavior of metacognitive thinking, as the teachers did not think they need to make a great deal of efforts to perform the work in the classroom or focus on non-enjoyable teaching tasks, or there are difficulties that impede the achievement of educational goals.

The result of this question differs with the studies of (Lokmani, 2012, Al-Qudah, 2014 and Barbakh, 2016), which found that the degree of possession of teaching habits of mind teaching among the sample of the study was high, because of the difference of study samples in those studies.

\section{Question 2: What is the level of positive behavior among teachers of social studies of the lower basic stage?}

To answer this question, the arithmetic means and standard deviations of the scores of the sample were calculated on the area of positive behavior scale. Table (7) includes the results:

Table 7. The Arithmetic Means and Standard Deviations of Sample Scores in the Areas of Positive Behavior Scale

\begin{tabular}{lllccl}
\hline rank & $\begin{array}{l}\text { Field } \\
\text { number }\end{array}$ & Level and areas of positive behavior & Mean & $\begin{array}{l}\text { Standard } \\
\text { deviation }\end{array}$ & level \\
\hline 1 & 1 & Personal positive behavior & 2.34 & .261 & High \\
2 & 2 & Academic positive behavior & 2.02 & .425 & Mean \\
Macro Scale & & 2.18 & .292 & Mean \\
\hline
\end{tabular}


Table (7) has shown that positive behavior level occurs within intermediate level. The field of positive personal behavior has the highest mean, followed by the positive academic behavior in the second and last rank. The researcher attributes this result to the result of previous question.

The role of the social studies teacher in the educational stage in which he is teaching, is characterized by guiding the mental and emotional development, and the saturation of learners personal behaviors - due to the age of study sample of students - in this educational stage, which forms the positive behaviors of a personal nature through effectiveness - albeit at the intermediate level as evidenced by the previous results - in facing problems in the classroom environment, and his feelings that he is calm and psychologically confident and self-satisfied, which represents the reality of social studies message in this necessary educational stage to build the personal skills of behaviors more than the cognitive and academic aspects. The results of this study are consistent with the results of the study of (Shaqoura, 2013) in the ranking of positive behavior levels of study sample and its difference. and it is different with the study of Barbakh (2015), which found that positive behavior manifestations was high among the sample of the study.

Question 3: Is there a statistically significant relationship between the teaching habits of mind and the positive behavior of social studies teachers at the lower basic stage?

To answer this question, the correlation coefficients between the total and sub-scores of the responses of sample were calculated on the measures of the teaching habits of mind and positive behavior. Table (8) shows the results.

Table 8. Correlation Coefficients between the Scores of the Study Sample Subjects on the Areas of Teaching Habits of Mind Scale and the Macro Scale, and the Positive Behavior Scale and Macro Scale

\begin{tabular}{lllll}
\hline Relationship & Statistics & $\begin{array}{l}\text { Personal } \\
\text { behavior }\end{array}$ & $\begin{array}{l}\text { Positive } \\
\text { Peademic } \\
\text { Positive Behavior }\end{array}$ & $\begin{array}{l}\text { Positive } \\
\text { behavior }\end{array}$ \\
\hline Persisting & Correlation coefficient & $0.271^{*}$ & $0.476^{* *}$ & $0.467^{* *}$ \\
Managing Impulsivity & Statistical significance & .036 & .000 & .000 \\
& Correlation coefficient & -097 & $0.292^{*}$ & .169 \\
Listening with Understanding & Statistical significance & .462 & .024 & .196 \\
and Empathy & Correlation coefficient & .166 & $0.630^{* *}$ & $0.555^{* *}$ \\
Thinking Flexibility & Statistical significance & .098 & .000 & .000 \\
& Correlation coefficient & $0.794^{* *}$ & $0.845^{* *}$ & $0.969^{* *}$ \\
Thinking about Thinking / & Statistical significance & .000 & .000 & .000 \\
Metacognitive thinking & Correlation coefficient & $0.440^{* *}$ & $0.779^{* *}$ & $0.763^{* *}$ \\
Creating, Imagery and & Statistical significance & .000 & .000 & .000 \\
Innovating & Correlation coefficient & $0.719^{* *}$ & $0.731^{* *}$ & $0.853^{* *}$ \\
Learning Continuously & Statistical significance & .000 & .000 & .000 \\
& Correlation coefficient & $0.489^{* *}$ & $0.582^{* *}$ & $0.642^{* *}$ \\
Finding Humor & Statistical significance & .000 & .000 & .000 \\
& Correlation coefficient & $0.626^{* *}$ & $0.416^{* *}$ & $0.582^{* *}$ \\
Teaching Habits of mind & Statistical significance & .000 & .001 & .000 \\
& Correlation coefficient & $0.524^{* *}$ & $0.746^{* *}$ & $0.777^{* *}$ \\
\hline
\end{tabular}

* Significance level of 0.05

** Significance level of 0.01

Table (8) shows that positive correlation coefficients are statistically significant at the significance level $(\alpha=0.05)$ among the area of teaching habits of mind scale, namely (Persisting; Managing Impulsivity; Listening with Understanding and Empathy; Thinking Flexibility; Thinking about Thinking/Metacognitive thinking; Creating, Imagery and Innovating; Learning Continuously; Finding Humor) and the scale as a whole, and the areas of positive academic behavior scale (personal positive behavior, and academic positive behavior) and the macro scale. This result seems logical despite the intermediate level of both the teaching habits of mind and the positive behaviors. As evidenced by the results of the previous questions, each of the teaching habits of mind and positive behaviors 
complement each other in the construction and integration of individual personality, as confirmed by some studies about the importance of mental habits in improving the individual behavior and in his thinking as a study of (Al-Nuwab \& Hussein, 2013), and it agreed with the study of Barbakh (2015) that showed there was a statistically significant positive relationship among all the dimensions of the habits of mind and the total score of the scale of positive behavior, and positive social behavior.

Question 4: Are there any statistically significant differences in teaching habits of mind of the social studies teachers in the lower basic stage depending on the variables (gender, experience, and educational qualification)?

To answer this question, the arithmetic means and the standard deviations of the scores of the sample were extracted on the scale of the teaching habits of mind and its different fields in light of the study variables; Table (9) summarizes the results.

Table 9. The Arithmetic Means and the Standard Deviations of the Scores of the Sample on the Measure of the Teaching Habits of the Mind According to the Variables of the Study

\begin{tabular}{llcl}
\hline Variables & Levels of variables & Mean & standard deviation \\
\hline \multirow{2}{*}{ Gender } & Male & 2.17 & .460 \\
& female & 2.13 & 3.99 \\
Qualification & BA & 2.07 & .333 \\
& Postgraduate & 2.26 & .509 \\
Experience & $1-5$ years & 1.89 & .361 \\
& 6 - 10 years & 2.13 & 371 \\
& A many of 10 years & 2.54 & 3.00 \\
\hline
\end{tabular}

Is evident in table (9) the existence of apparent differences between arithmetic means of the scores of respondents on the teaching habits of mind scale in the light of their distribution according to the study variables. To test the significance of these differences, 3-WAYS ANOVA (without interactions) was conducted for the macro score. Table (10) summarizes the results.

Table 10. 3-WAYS ANOVA (without interactions) of the Sample Scores in Light of the Study Variables

\begin{tabular}{lccccc}
\hline Source of difference & Total of squares & $\begin{array}{l}\text { Degree of } \\
\text { freedom }\end{array}$ & $\begin{array}{l}\text { Mean of total } \\
\text { squares }\end{array}$ & $\begin{array}{l}\text { Value F } \\
\text { Calculated }\end{array}$ & $\begin{array}{l}\text { Statistic } \\
\text { Significance }\end{array}$ \\
\hline Gender & .443 & 1 & .443 & 3.694 & .060 \\
Qualification & .016 & 1 & .016 & 130 & 719 \\
Experience & 3.531 & 2 & 1.765 & 14.723 & $* .000$ \\
The error & 6.595 & 55 & .120 & & \\
Total / macro & 289.650 & 60 & & & \\
$*$ significant at the significance level $(\alpha=0.05)$ & & & & \\
\hline
\end{tabular}

It is clear in table (10) that there are statistically significant differences $(\alpha=0.05)$ attributed to the variable of experience and these differences attributed to the benefit of experts who have more than 10 years of experience. The results also showed that there were no statistically significant differences $(\alpha=0.05)$ attributed to the variables of study (Gender, and academic qualification).

The arithmetic means and the standard deviations of the sample scores on the teaching habits of mind scale and its dimensions were calculated according to the study variables. Table (11) shows this as follows: 
Table 11. The Arithmetic Means and the Standard Deviations of the Sample Scores on the Teaching Habits of Mind Scale According to the Study Variables

\begin{tabular}{|c|c|c|c|c|c|c|c|c|c|c|}
\hline Variables & Categories & Statistics & Persisting & $\begin{array}{l}\text { Managing } \\
\text { Impulsivity }\end{array}$ & $\begin{array}{l}\text { Listening with } \\
\text { Understanding } \\
\text { and Empathy }\end{array}$ & $\begin{array}{l}\text { Thinking } \\
\text { Flexibility }\end{array}$ & $\begin{array}{l}\text { Thinking } \\
\text { about } \\
\text { Thinking/ } \\
\text { Metacognitive } \\
\text { thinking }\end{array}$ & $\begin{array}{l}\text { Creating, } \\
\text { Imagery and } \\
\text { Innovating }\end{array}$ & $\begin{array}{l}\text { Learning } \\
\text { Continuously }\end{array}$ & $\begin{array}{l}\text { Finding } \\
\text { Humor }\end{array}$ \\
\hline \multirow{4}{*}{ Gender } & \multirow[b]{2}{*}{ Male } & Mean & 2.00 & 2.24 & 2.17 & 2.20 & 2.19 & 2.35 & 2.02 & 2.24 \\
\hline & & $\begin{array}{l}\text { standard } \\
\text { deviation }\end{array}$ & .63 & 72 & 61 & .58 & 48 & .53 & .45 & .63 \\
\hline & \multirow[b]{2}{*}{ female } & MEAN & 2.08 & 2.06 & 2.14 & 1.97 & 2.24 & 2.05 & 2.21 & 2.36 \\
\hline & & $\begin{array}{l}\text { standard } \\
\text { deviation }\end{array}$ & .78 & .50 & 71 & .40 & .45 & .27 & 41 & 59 \\
\hline \multirow{4}{*}{$\begin{array}{l}\text { Educational } \\
\text { Qualification }\end{array}$} & \multirow[b]{2}{*}{ BA } & MEAN & 1.90 & 2.05 & 2.12 & 1.97 & 2.08 & 2.14 & 2.02 & 2.31 \\
\hline & & $\begin{array}{l}\text { standard } \\
\text { deviation }\end{array}$ & 59 & 62 & .63 & 44 & .30 & 41 & 34 & .63 \\
\hline & \multirow[b]{2}{*}{ Postgraduate } & MEAN & 2.23 & 2.26 & 2.19 & 2.22 & 2.40 & 2.25 & 2.26 & 2.29 \\
\hline & & $\begin{array}{l}\text { standard } \\
\text { deviation }\end{array}$ & .81 & 59 & 71 & 54 & 57 & 46 & 51 & 59 \\
\hline \multirow{6}{*}{ Experience } & \multirow[b]{2}{*}{$1-5$ years } & MEAN & 1.70 & 1.85 & 1.73 & 2.00 & 1.91 & 2.12 & 1.81 & 2.04 \\
\hline & & $\begin{array}{l}\text { standard } \\
\text { deviation }\end{array}$ & 49 & .58 & 49 & 65 & .28 & .56 & 44 & 72 \\
\hline & \multirow[b]{2}{*}{$6-10$ years } & MEAN & 1.98 & 2.35 & 2.10 & 1.94 & 2.18 & 2.07 & 2.15 & 2.26 \\
\hline & & $\begin{array}{l}\text { standard } \\
\text { deviation }\end{array}$ & .77 & 47 & 69 & .35 & .40 & .32 & .35 & .56 \\
\hline & \multirow{2}{*}{$\begin{array}{l}\text { More than } 10 \\
\text { years }\end{array}$} & MEAN & 2.60 & 2.20 & 2.80 & 2.40 & 2.68 & 2.48 & 2.48 & 2.72 \\
\hline & & $\begin{array}{l}\text { standard } \\
\text { deviation }\end{array}$ & 51 & 74 & .00 & 34 & 41 & .28 & .25 & 17 \\
\hline
\end{tabular}

Table (11) shows that there are apparent differences between the arithmetic means of the sample scores on the teaching habits of mind scale in the light of its distribution according to the study variables, which justifies to conduct the 3-WAYS MANOVA without interaction, and Table 12 shows the results, as follows.

Table 12. The 3-WAYS MANOVA without Interaction Analysis on the Scores of the Sample on the Teaching Habits of Mind Scale

\begin{tabular}{llccccc}
\hline \multirow{2}{*}{ Impact } & Multi-test & $\begin{array}{c}\text { Multi-test value Total } \\
\text { (F) }\end{array}$ & $\begin{array}{c}\text { Value hypothesis } \\
\text { freedom }\end{array}$ & $\begin{array}{l}\text { of Degree } \\
\text { error } \\
\text { freedom }\end{array}$ & $\begin{array}{c}\text { of } \\
\text { Significance } \\
\text { Statistics }\end{array}$ \\
\hline Gender & Hotelling's Trace & .991 & 5.945 & 8.000 & 48,000 & $* .000$ \\
$\begin{array}{l}\text { Educational } \\
\text { Qualification }\end{array}$ & Hotelling's Trace & .774 & 4.642 & 8.000 & 48,000 & $* .000$ \\
Experience & Wilks' Lambda & .115 & 11.657 & 16.000 & 96,000 & $* .000$ \\
\hline
\end{tabular}

Table (12) shows that there are significant differences $(\alpha=0.05)$ in the areas of the teaching habits of the mind scale due to the study variables (gender, qualification, experience). To verify this result, the 3-WAYS MANOVA without interaction analysis was conducted on the scores of the sample of the teaching habits of mind. Table 13 summarizes the results. 
Table 13. The 3-WAYS MANOVA without Interaction Analysis on the Scores of the Sample on the Teaching Habits of Mind Scale

\begin{tabular}{|c|c|c|c|c|c|c|}
\hline $\begin{array}{l}\text { Variance } \\
\text { Source }\end{array}$ & dependent variable & $\begin{array}{l}\text { sum } \\
\text { of } \\
\text { squares }\end{array}$ & $\begin{array}{l}\text { Freedon } \\
\text { Degree }\end{array}$ & $\begin{array}{l}\text { Average } \\
\text { of squares } \\
\text { sum }\end{array}$ & $\begin{array}{l}\text { Calculated } \\
\text { Value (F) }\end{array}$ & $\begin{array}{l}\text { Statistical } \\
\text { Significance }\end{array}$ \\
\hline \multirow{8}{*}{ Gender } & Persisting & .079 & 1 & .079 & .197 & 659 \\
\hline & managing impulsivity & 2.384 & 1 & 2.384 & 7.896 & $* .007$ \\
\hline & Listening with Understanding and Empathy & 910 & 1 & 910 & 3.445 & .069 \\
\hline & Thinking Flexibility & .983 & 1 & .983 & 4.852 & $* .032$ \\
\hline & Thinking about Thinking / Metacognitive thinking & 148 & 1 & 148 & 1.154 & .288 \\
\hline & Creating, Imagery and Innovating & 1.716 & 1 & 1.716 & 12.230 & $* .001$ \\
\hline & Learning Continuously & .26 & 1 & .26 & .194 & .662 \\
\hline & Finding Humor & .000 & 1 & .000 & .001 & .973 \\
\hline \multirow{8}{*}{$\begin{array}{l}\text { Educational } \\
\text { Qualification }\end{array}$} & Persisting & .209 & 1 & .209 & 51 & .475 \\
\hline & managing impulsivity & .177 & 1 & .177 & 719 & .400 \\
\hline & Listening with Understanding and Empathy & 609 & 1 & 609 & 2.305 & .135 \\
\hline & Thinking Flexibility & .392 & 1 & .392 & 1.935 & .170 \\
\hline & Thinking about Thinking / Metacognitive thinking & .304 & 1 & .304 & 2.364 & 130 \\
\hline & Creating, Imagery and Innovating & .009 & 1 & .009 & .064 & .801 \\
\hline & Learning Continuously & .108 & 1 & .108 & .813 & 371 \\
\hline & Finding Humor & 552 & 1 & 552 & 1.748 & .192 \\
\hline \multirow{8}{*}{ Experience } & Persisting & 5.726 & 2 & 2.863 & 7.111 & $* .002$ \\
\hline & managing impulsivity & 4.163 & 2 & 2.082 & 6.896 & $* .002$ \\
\hline & Listening with Understanding and Empathy & 11.325 & 2 & 5.662 & 21.431 & $* .000$ \\
\hline & Thinking Flexibility & 1.692 & 2 & .846 & 4.174 & $* .021$ \\
\hline & Thinking about Thinking / Metacognitive thinking & 4.038 & 2 & 2.019 & 15.690 & $* .000$ \\
\hline & Creating, Imagery and Innovating & 1.819 & 2 & 910 & 6.482 & $* .003$ \\
\hline & Learning Continuously & 2.714 & 2 & 1.357 & 10.185 & $* .000$ \\
\hline & Finding Humor & 4.378 & 2 & 2.189 & 6.929 & $* .002$ \\
\hline \multirow{8}{*}{ The error } & Persisting & 22.142 & 55 & .403 & & \\
\hline & managing impulsivity & 16.603 & 55 & .302 & & \\
\hline & Listening with Understanding and Empathy & 14.532 & 55 & .264 & & \\
\hline & Thinking Flexibility & 11.146 & 55 & .203 & & \\
\hline & Thinking about Thinking / Metacognitive thinking & 7.077 & 55 & .129 & & \\
\hline & Creating, Imagery and Innovating & 7.718 & 55 & 140 & & \\
\hline & Learning Continuously & 7.329 & 55 & .133 & & \\
\hline & Finding Humor & 17.377 & 55 & 316 & & \\
\hline \multirow{8}{*}{ Total } & Persisting & 280.040 & 60 & & & \\
\hline & managing impulsivity & 297.944 & 60 & & & \\
\hline & Listening with Understanding and Empathy & 304.160 & 60 & & & \\
\hline & Thinking Flexibility & 273.028 & 60 & & & \\
\hline & Thinking about Thinking / Metacognitive thinking & 307.480 & 60 & & & \\
\hline & Creating, Imagery and Innovating & 298.920 & 60 & & & \\
\hline & Learning Continuously & 281.880 & 60 & & & \\
\hline & Finding Humor & 340.280 & 60 & & & \\
\hline * significant a & it the significance level of $(\alpha=0.05)$ & & & & & \\
\hline
\end{tabular}


Table 13 shows that there are statistically significant differences $(0=0.05)$ due to the gender variable in the level of managing impulsivity, thinking flexibility, Creating, Imagery and Innovating. These differences are attributed to the benefit of males. There are also statistically significant differences between the scores of the sample on the fields of study according to the variable of experience, and these differences are attributed to the benefit of the experience of more than 10 years.

This result can be explained by the fact that male teachers have a preference for thinking quietly and carefully in difficult situations, thinking carefully before making decisions, having flexibility in receiving information, providing different solutions to problems, and having a preference for motivating subjects.

The male's mind is characterized by the concept of classified thinking, in contrast to the female's mind that tends to the networking system thinking and behavior. The man/male person has a greater ability to separate among the treatments of things and isolate the previous circumstance from the current one, and even in time of anger, he resorted to isolation, that is, entering to his cave, as it is said, (John, 2008,72). The woman/female is characterized by the networking mentality that links constantly attitudes and things, hence, a former psychological feeling may be reflected in an existing circumstance, giving a hint of inflexibility and the lack of mood.

The researcher also believes that the gender roles of men and women play a role in that issue. The responsibility is multiple for the women to take care of household affairs and to follow the requirements of the household, including the tasks that keep the woman busy. While the male mentality is closer to impartiality, which is the most important role in guidance, both in the classroom or the home environment, and thus the depth of thinking is similar in the direction of behavioral educational construction, whether for his children or his students. The results of this question in terms of variable - gender in favor of males were compatible with the results of (Barbakh, 2015) study at the level of habits of mind.

As for the existence of statistical significance for the benefit of the category (10 years of experience), the researcher sees the logic of this result because the teaching habits of mind enjoy the deep awareness that does not appear clearly in the performance practice in the field of teaching only after a period of the performance in teaching field.

In the first years of teaching experience, the teachers explores the school environment, administrative system, and psychological atmosphere; achievement of self-teaching, recording of psychological presence in the hearts of students. In addition, the teacher starts to know the regulations and instructions in the first years of teaching experience. Resulting into the state of stability and depth performance in teaching practice by teachers as represented in the sample of this study in the category the experts who have (10 years) of experience. The results are different with the results of the study of Luqmani (2012) which found that there were no statically significant difference, attributed to the variables of the study (age, educational qualification, years of educational experience, and the number of training courses).

Question 5: Are there statistically significant differences in the positive behavior of the social studies teachers of the lower basic stage according to the variables (gender, experience, qualification)?

To answer this question, the arithmetic means and the standard deviations of the scores of the sample were extracted on the positive behavior scale and its different fields in light of the study variables. Table (14) summarizes the results.

Table 14. The Arithmetic Means and the Standard Deviations of Sample the on the Positive Behavior Scale in Light of the Study Variables

\begin{tabular}{llll}
\hline Variables & Levels of variables & arithmetic mean & standard deviation \\
\hline \multirow{2}{*}{ Gender } & Male & $2.24)$ & .314 \\
& female & 2.12 & .261 \\
Educational Qualification & BA & 2.11 & .253 \\
& Postgraduate & 2.26 & .320 \\
\multirow{5}{*}{ Experience } & $1-5$ years & 2.12 & .359 \\
& 6 - 10 years & 2.08 & .213 \\
& More than 10 years & 2.42 & 148 \\
\hline
\end{tabular}


Table (14) shows that there are apparent differences among the arithmetic means of the sample scores on the positive behavior scale in light of their distribution according to the variables of the study. To test the significance of these differences, 3-WAYS ANOVA without interactions was performed for the total score. Table (15) summarizes the results.

Table 15. 3-WAYS ANOVA without Interactions of the Sample Scores in Light of the Study Variables

\begin{tabular}{llllll}
\hline Variance Source & Sum of squares & Freedom Degree & $\begin{array}{l}\text { Means of } \\
\text { squares sum }\end{array}$ & $\begin{array}{l}\text { Calculated } \\
\text { Value (F) }\end{array}$ & $\begin{array}{l}\text { Statistical } \\
\text { Significance }\end{array}$ \\
\hline Gender & .304 & 1 & .304 & 4.870 & $* .32$ \\
Educational Qualification & 110 & 1 & 110 & 1.757 & .191 \\
Experience & 959 & 2 & .480 & 7.675 & $* .001$ \\
Error & 3.437 & 55 & .062 & & \\
Total & 290.388 & 60 & & & \\
$*$ significance level of $\alpha=0.05$ & & & & \\
\hline
\end{tabular}

Table (15) shows that there are statistically significant differences $(\alpha=0.05)$ due to the variable of experience. These differences are due to the benefit of the experienced persons for more than 10 years. The results also showed that there are statistically significant differences $(\alpha=0.05)$ due to the variable of gender and these differences are due to the benefit of males. While the results did not show significant differences $(\alpha=0.05)$ that are attributed to the variable of educational qualification.

The arithmetic means and the standard deviations of the sample scores on the positive behavior scale and its dimensions were calculated in light of the study variables. Table (16) summarizes the results.

Table 16. The Arithmetic Means and the Standard Deviations of the Sample Scores on the Positive Behavior Scale in Light of the Study Variables

\begin{tabular}{|c|c|c|c|c|}
\hline Variables & Categories & Statistics & $\begin{array}{l}\text { Personal } \\
\text { Behavior }\end{array}$ & $\begin{array}{l}\text { Positive Academic } \\
\text { positive Behavior }\end{array}$ \\
\hline \multirow{4}{*}{ Gender } & \multirow{2}{*}{ Male } & Arithmetic Mean & 2.39 & 2.11 \\
\hline & & Standard Deviation & .33 & 44 \\
\hline & \multirow{2}{*}{ female } & Arithmetic Mean & 2.30 & 1.94 \\
\hline & & Standard Deviation & .18 & .40 \\
\hline \multirow{4}{*}{$\begin{array}{l}\text { Educational } \\
\text { Qualification }\end{array}$} & \multirow{2}{*}{ BA } & Arithmetic Mean & 2.34 & 1.89 \\
\hline & & Standard Deviation & .27 & .33 \\
\hline & \multirow{2}{*}{ Postgraduate } & Arithmetic Mean & 2.35 & 2.18 \\
\hline & & standard deviation & .25 & 48 \\
\hline \multirow{6}{*}{ Experience } & \multirow{4}{*}{$1-5$ years } & Arithmetic Mean & 2.42 & 1.84 \\
\hline & & Standard deviation $\mathrm{j}$ & 37 & .40 \\
\hline & & Arithmetic Mean & 2.27 & 1.89 \\
\hline & & Standard Deviation & .20 & .32 \\
\hline & \multirow{2}{*}{ More than 10 years } & Arithmetic Mean & 2.36 & 2.48 \\
\hline & & Standard deviation & 12 & 24 \\
\hline
\end{tabular}

Table (16) shows that there are apparent differences between the arithmetic means of the sample scores on the positive behavior scale in light of their distribution according to the variables of the study, which justify the analysis of the 3-WAYS MANOVA without interaction. Table 17 shows the results. As follows. 
Table 17. The 3-WAYS MANOVA Results of the Sample Scores on the Positive Behavior Scale

\begin{tabular}{lllllll}
\hline Impact & Multi-test & Multi-test value & $\begin{array}{l}\text { Calculated Total } \\
\text { Value }(\mathrm{F})\end{array}$ & $\begin{array}{l}\text { Degree of } \\
\text { hypothesis } \\
\text { freedom }\end{array}$ & $\begin{array}{l}\text { Degree of } \\
\text { error } \\
\text { freedom }\end{array}$ & $\begin{array}{l}\text { Significance } \\
\text { Statistics }\end{array}$ \\
\hline Gender & Hotelling's Trace & .211 & $5.698 \mathrm{~b}$ & 2.000 & 54,000 & $* .006$ \\
$\begin{array}{l}\text { Educational } \\
\text { Qualification } \\
\text { Experience }\end{array}$ & Hotelling's Trace & .058 & $1.571 \mathrm{~b}$ & 2.000 & 54,000 & .177 \\
\hline
\end{tabular}

Table (17) shows that there are statistically significant differences $(\alpha=0.05)$ in the fields of positive behavior scale due to the study variables (gender, qualification, experience). To verify this result, the 3-WAYS MANOVA without interaction analysis was conducted on the scores of the sample for positive behavior scale. Table 18 summarizes the results.

Table 18. 3-WAYS MANOVA without Interaction Analysis on the Scores of the Sample for Positive Behavior Scale

\begin{tabular}{lllllll}
\hline $\begin{array}{l}\text { Source } \\
\text { variance }\end{array}$ & Dependent variable & $\begin{array}{l}\text { sum } \\
\text { of squares }\end{array}$ & $\begin{array}{l}\text { Degree } \\
\text { Freedom }\end{array}$ & $\begin{array}{l}\text { Squares } \\
\text { Mean }\end{array}$ & $\begin{array}{l}\text { Calculated } \\
\text { Value (F) }\end{array}$ & $\begin{array}{l}\text { Statistical } \\
\text { Significance }\end{array}$ \\
\hline \multirow{2}{*}{ Gender } & Personal positive behavior & .023 & 1 & .023 & .335 & .565 \\
& Academic Positive Behavior & .908 & 1 & .908 & 9.681 & $* .003$ \\
Qualification & Personal positive behavior & .019 & 1 & .019 & .280 & .599 \\
& Academic Positive Behavior & .276 & 1 & .276 & 2.939 & .092 \\
Experience & Personal positive behavior & 171. & 2 & .085 & 1.264 & .291 \\
& Academic Positive Behavior & 3.748 & 2 & 1.874 & 19.980 & $* .000$ \\
\multirow{5}{*}{ The error } & Personal positive behavior & 3.716 & 55 & .068 & & \\
& Academic Positive Behavior & 5.159 & 55 & .094 & & \\
\multirow{2}{*}{ Total/ Macro } & Personal positive behavior & 333.480 & 60 & & & \\
\multirow{2}{*}{ * Function at the level of $\alpha=0.05$} & & & & & & \\
\hline
\end{tabular}

It is evident in the table (18) that there are statistically significant differences $(\alpha=0.05)$ due to the variable (gender) in the field of positive academic behavior level, and these differences attributed in favor of males. It is evident that there are statistically significant differences between the scores of respondents on the field of academic positive behavior depending on the positive experience variable. These differences are attributed in favor of the experts who have more than 10 years of experience.

The result of this question is consistent with the result of the previous question and its justifications. The researcher believes that the gender role of men and women plays an important role in guiding personal and academic behaviors.

The behavioral responsibility is multiple for women to take care of household affairs, follow up the household requirements and raise children and follow up the needs of children. While, the behavioral responsibility for males is closer to the impartiality, which represents a single role in the direction of academic terms, both in the classroom or home environment. Thus, the depth of thinking is similar in the direction of behavioral educational construction, whether for his children or his students. The result of this question in terms of variable - gender in favor of maleswas compatible with the results of (Berber, 2015) study at the level of positive behaviors. This result is different with Shaqura(2013) is study that indicated There were statistically significant differences of for the gender variable and for the females of the study sample.

As for the existence of statistical significance for the benefit of the category (10 years of experience), the researcher sees the logic of this result because the academic positive behavior of teaching enjoys the deep awareness that does not appear clearly in the performance practice in the field of teaching only after a period of the performance in teaching field. 
In the first years of teaching experience, the teacher explores the school environment, administrative system, educational content and building trust with students. Resulting into the state of stability and depth performance in teaching practice by teachers as represented by the sample of this study in the category the experts who have (10 years) of experience.

\section{Recommendations}

1) Integrating the habits of mind and the positive behaviors associated with teaching in the programs of preparing social studies teachers, and in the social studies courses in the programs of universities and for all levels of study.

2) Holding workshops and training courses for newly graduated social studies teachers to raise their level of competence in supporting ways to achieve mental habits and positive behaviors associated with teaching. 3) The need for further research and studies on the subject of habits of mind and positive behaviors associated with teaching, and the factors, which impact on different new classes, and other classified variables, and how to develop those studies by the social studies teachers conclude the educational, real and excellent outcomes.

\section{References}

Abd Al-Khaliq, Ahmad Muhammad. (2004). Arabic version of the Snyder scale of hope, psychological studies. Egyptian Association of Psychologists, 14(2), 160-205.

Abdulmaksoud, Abeer. (2012). The effectiveness of the training program based on emotional intelligence in the development of positive behavior in a sample of high school talented graduates, master thesis, the Faculty of Arts, Department of Psychology, Ain Shams University.

Al- qudah, mohammad. (2014). Habits of mind and their relationship to the motivation of achievement among the students of the Faculty of Education in King Saud University. Journal of Arab Studies for Development and Excellence, 5(8), 33-59.

Al-Luqmani, Iman. (2012). Habits of Mind for Kindergarten Teachers in Makkah Al-Mukaramah, and its Relation to Some Variables, Master Thesis, Faculty of Education, Umm Al-Qura University, Saudi Arabia.

Al-Nuwab, Naji Mahmoud, Hussein, \& Mohamed Ibrahim. (2013). The habits of mind and high level thinking and their relation to the self-efficacy of students of faculties of education. Journal of Human Sciences, 19, 172-1149.

Arian, Samira Attia. (2010). The habits of mind and the skills of social intelligence required for the teacher of Philosophy and Sociology in the 21st Century. Girls College, Ain Shams University, Egypt.

Barbakh, Elham. (2015). The Habits of the Mind and Their Relationship with Positive Behaviors of Al Azhar University Students in Gaza. Master Thesis, Department of Psychology, Al-Azhar University, Gaza.

Campbell, J. (2006). Theorizing Habits of Mind as a Framework for Learning. Paper Presented at the Australian Association for Research in Education (AARE) Annual Conference Adelaide, Central Queensland University. Retrieved 10/7/2016 from: http://www.aare.edu.au/camo610

Costa, A., \& Kallick, B. (2000). Discovering and Exploring Habits of Mind. ASCD. Alexandria, Victoria USA.

Costa, A., \& Kellick, B. (2009). Learning and leading with Habits of Mind: 16 Essential Characteristics for Success. Association for Supervision and Curriculum Development, (ASCD) Alexandria, Virginia USA.

Costa, Arthur, Kallek, \& Pina. (2003). Explore habits of mind. (Translated by Hatem Abdel Ghani). Dhahran National Schools, Riyadh: Dar Al-Kitab Al-Tarbawi for Publishing and Distribution.

John, Gray (2008). Men Are from Mars, Women Are from Venus, translated by Sulaiman Al-Sabe', Dar Al Amal, Irbid Jordan.

Khoon, A. (2005). The Impact of Habits of Mind on Student' Achievement, 47(1), Retrieved from www.iproed.com/AR/Paper/sec Xinmin2.htm- 54k- cached

Mahmoud, Abdul Razek Mukhtar. (2012). A program based on the real teaching standards to develop the skills of creative teachers of Arabic language and the habits of mind produced by their students. Journal of Education Faculty, 28(1), 45-78.

Marazano, R. (1992). A different Kind of Classroom: Teaching with Dimensions of Learning. Association for Supervision and Curriculum Development, Alexandria Virginia USA. 
Nofal, Mohammed Bakr. (2008). Common Habits of Mind among Primary Stage Students in UNRWA Schools in Jordan, Journal of the student-teacher (UNRWA / UNESCO), 1, 33-75.

Nofal, Mohammed Bakr. (2010). Practical applications in the development of thinking using the habits of mind. Version 2, Amman: Dar Al Masirah.

Rodgers, S. (2008). Infusing Habits of mind in Lessons. Journal of Learning and teaching, 2(1), 30- 96.

Shaquoura, Diaa Hassan. (2013). Positive Behavior and its relation to the thinking produced by students of technical colleges in the governorates of Gaza. Master Thesis, Department of Psychology, Al-Azhar University, Gaza.

Thomas, Terns. (2005). Social Studies in Elementary School, translated by Fakhri Rashid Khadr, Dubai, Dar Al Qalam for Publishing and Distribution. 